\title{
Boreal forest fires in 1997 and 1998: a seasonal comparison using transport model simulations and measurement data
}

\author{
N. Spichtinger ${ }^{1}$, R. Damoah ${ }^{1}$, S. Eckhardt ${ }^{1}$, C. Forster ${ }^{1}$, P. James ${ }^{1}$, S. Beirle ${ }^{2}$, T. Marbach ${ }^{2}$, T. Wagner ${ }^{2}$, P.C. Novelli ${ }^{3}$, \\ and A. Stohl ${ }^{4}$ \\ ${ }^{1}$ Department of Ecology, Technical University of Munich, Germany \\ ${ }^{2}$ Institute for Environmental Physics, University of Heidelberg, Germany \\ ${ }^{3}$ NOAA, Climate Monitoring and Diagnostics Laboratory, Colorado \\ ${ }^{4}$ Cooperative Inst. for Research in Environmental Sciences (CIRES), Univ. of Colorado/NOAA Aeronomy Laboratory, USA
}

Received: 9 January 2004 - Published in Atmos. Chem. Phys. Discuss.: 18 May 2004

Revised: 16 August 2004 - Accepted: 19 August 2004 - Published: 14 September 2004

Abstract. Forest fire emissions have a strong impact on the concentrations of trace gases and aerosols in the atmosphere. In order to quantify the influence of boreal forest fire emissions on the atmospheric composition, the fire seasons of 1997 and 1998 are compared in this paper. Fire activity in 1998 was very strong, especially over Canada and Eastern Siberia, whereas it was much weaker in 1997. According to burned area estimates the burning in 1998 was more than six times as intense as in 1997. Based on hot spot locations derived from ATSR (Along Track Scanning Radiometer) data and official burned area data, fire emissions were estimated and their transport was simulated with a Lagrangian tracer transport model. Siberian and Canadian forest fire tracers were distinguished to investigate the transport of both separately. The fire emissions were transported even over intercontinental distances. Due to the El Niño induced meteorological situation, transport from Siberia to Canada was enhanced in 1998. Siberian fire emissions were transported towards Canada and contributed concentrations more than twice as high as those due to Canada's own CO emissions by fires. In 1998 both tracers arrive at higher latitudes over Europe, which is due to a higher North Atlantic Oscillation (NAO) index in 1998. The simulated emission plumes are compared to CMDL (Climate Monitoring and Diagnostics Laboratory) $\mathrm{CO}_{2}$ and $\mathrm{CO}$ data, Total Ozone Mapping Spectrometer (TOMS) aerosol index (AI) data and Global Ozone Monitoring Experiment (GOME) tropospheric $\mathrm{NO}_{2}$ and HCHO columns. All the data show clearly enhanced signals during the burning season of 1998 compared to 1997. The results of the model simulation are in good agreement with ground-based as well as satellite-based measurements.

Correspondence to: N. Spichtinger

(spichtinger@forst.tu-muenchen.de)

\section{Introduction}

Biomass burning causes large emissions of carbon dioxide $\left(\mathrm{CO}_{2}\right)$, carbon monoxide $(\mathrm{CO})$, nitrogen oxides $\left(\mathrm{NO}_{\mathrm{x}}\right)$, methane $\left(\mathrm{CH}_{4}\right)$, aerosols and other trace substances, which influence the concentrations of trace gases and aerosols in the atmosphere and affect the atmosphere in various ways. $\mathrm{CO}_{2}$ and $\mathrm{CH}_{4}$ are important greenhouse gases, contributing to global warming. The solar radiation budget is strongly affected by the aerosols emitted by the forest fires, too (Asakuma et al., 2002; Torres et al., 1998, 2002). Finally, forest fires can even be a source of stratospheric aerosols (Fromm and Servranckx, 2003). Tropospheric chemistry is influenced by the emissions of $\mathrm{CO}$ and $\mathrm{NO}_{\mathrm{x}}$, precursors of tropospheric ozone $\left(\mathrm{O}_{3}\right)$ (Chan et al., 2003) - an effective greenhouse gas itself - , and nitric acid $\left(\mathrm{HNO}_{3}\right)$, a product which is part of the nitrogen chemical reaction cycle, leading to acid rain (Jaegle et al., 1998). Boreal fires emit relatively large quantities of $\mathrm{NO}_{\mathrm{x}}$ due to high burning temperatures, especially during the appearance of crown fires, which account for most of the areas burned in the boreal fire regime (Kajii et al., 2002; Cofer et al., 1998). Additionally, other trace gases are emitted like methyl bromide and methyl chlorine which are involved in catalytic cycles of stratospheric $\mathrm{O}_{3}$ destruction.

The input of biomass burning emissions into the atmosphere is often discussed as a phenomenon of the tropical rain forest and savannas (Crutzen and Merlet, 1990; Andreae et al., 2001; Andreae and Merlet, 2001). However, the boreal forest contains one third of the terrestrial carbon storage, boreal burning emits up to 20 percent of the global biomass burning CO (Conard and Ivanova, 1997) and temperature increases are expected as a consequence of climate change (Stocks et al., 1998) in the ecologically sensitive high 
Table 1. Areas burned [Mha] in Canada and Siberia during the years 1997 and 1998, according to different sources: a UNECE (1999), ${ }^{\mathrm{b}}$ Conard et al. (2002), ${ }^{\mathrm{c}}$ Kasischke and Bruhwiler (2003).

\begin{tabular}{ccc}
\hline Siberia & Canada & Year \\
\hline \multicolumn{3}{c}{ Area Burned } \\
0.98 & 0.62 & $1997^{\mathrm{a}}$ \\
5.34 & 4.71 & $1998^{\mathrm{a}}$ \\
13.3 & & $1998^{\mathrm{b}}$ \\
\hline boreal region & & \\
17.9 & & $1998^{\mathrm{c}}$ \\
\hline
\end{tabular}

Table 2. Hot spots detected on the basis of ATSR night-time data for the years 1997 to 2001 .

\begin{tabular}{ccc}
\hline & \multicolumn{2}{c}{ hot spot counts } \\
\hline year & Canada & Siberia \\
\hline 1997 & 974 & 6321 \\
1998 & 8701 & 21721 \\
1999 & 3588 & 5803 \\
2000 & 3469 & 8302 \\
2001 & 1797 & 5031 \\
\hline
\end{tabular}

northern latitudes, possibly leading to enhanced fire activity in the future (Flannigan, 1998). Furthermore, the lifetimes of many trace gases and aerosols in the atmosphere are much longer in the boreal region than in the tropics. Because low annual average temperatures and dryness lead to accumulation of ground fuel through slow decomposition processes, boreal fires consume large amounts of fuel, burn with high intensity and spread particularly fast. Furthermore, boreal fires are subjected to a strong interannual variability (Amiro et al., 2001). Finally, boreal forest fires are not only a local disturbance factor but, due to atmospheric transport processes, they affect tropospheric chemistry on regional (Kato et al., 2002; Tanimoto et al., 2000) and even continental and hemispheric scales (Fromm et al., 2000; Wotawa and Trainer, 2000; Forster et al., 2001; Spichtinger et al., 2001; Wotawa et al., 2001).

Boreal forest fires occur mainly from May to October (Lavoue et al., 2000) and are most frequent in Canada and Siberia. The 1998 burning season in the boreal region was much more active than the 1997 one (Table 1). 1998 was one of the worst five years since forest fires are recorded in Canada (Svidenko and Goldammer, 2001), and one of the most severe years during the last 15 years in Siberia (UNECE, 1999).

Strong burning is favoured by drought conditions and high temperatures (Svidenko and Goldammer, 2001; Kajii et al., 2002; French et al., 2003). Cahoon et al. (1994), for instance, described how high temperatures, dryness and strong winds lead to extensive forest fires in China in 1987. During the last three decades the burned area in the boreal region shows a positive trend, a consequence of increasing temperatures. Especially the years with very strong fire activity all coincided with positive temperature anomalies (Kasischke and Bruhwiler, 2003; Stocks et al., 1998; Flannigan, 1998). South East Siberia normally experiences dry anti cyclonic conditions in combination with the monsoon circulation until July and then shifts into a cyclonic humid situation. In 1998 midlatitude cyclones did not reach latitudes higher than $30^{\circ}-35^{\circ} \mathrm{N}$ and it remained dry and hot east of the Okhotsk Sea longer than normal (Efremov and Sheshukov, 2000). Fig. 1 shows maps of the temperature anomalies from June to August for the years 1997 and 1998, calculated using NCAR/NCEP reanalysis data. In 1998 most of the northern hemisphere features positive temperature anomalies. Regions with extremely high values, up to $4.5 \mathrm{~K}$, are found in the boreal burning regions in northern and central Canada and eastern Siberia, respectively. In 1998 in most parts of these regions high temperatures are combined with less than normal precipitation (Fig. 2). Thus, fire-favouring meteorological conditions prevailed in 1998 presumably due to the strong El Niño/Southern Oscillation event of 1997/1998 (Kita et al., 2000; Novelli et al., 2003; Duncan et al., 2003). In contrast, no large anomalies are found for 1997.

This paper compares measurement data from various sources (surface measurements of $\mathrm{CO}$ and $\mathrm{CO}_{2}$ from a flask sampling network, aerosol index values and columns of tropospheric $\mathrm{NO}_{2}$ and $\mathrm{HCHO}$ from satellite remote sensing) and transport model simulations for the years 1997 and 1998. In the next section, estimates for the areas burnt and the respective trace gas emissions in 1997 and 1998 are made. In Sect. 3, the measurement data and model simulations are described. In Sect. 4, results from the transport model simulations are shown, and in Sect. 5 analyses of the measurement data are presented. Finally, conclusions are drawn in Sect. 6.

\section{Areas burned and emissions}

Data on the areas burned and emissions from fires are the basis and at the same time the limiting factor for the quality of quantitative transport modelling of biomass burning plumes. Different estimates of total areas burned in Canada and Siberia are shown in Table 1. According to official data, more than 10 million ha were burned in both regions in 1998 (UNECE, 1999), which is more than six times the area burned in 1997. However, it is known that the Russian official data strongly underestimate the burned areas in Siberia (Conard and Ivanova, 1997; Conard et al., 2002), where a large number of forest fires remain undetected (Cahoon et al., 1994). Using remote sensing data, Kasischke and Bruhwiler (2003) estimated that 17.9 million ha forest burned in the boreal region in 1998, the largest area burned of the decade. For comparison, in 1997 an area of just 1.6 million ha has burned 


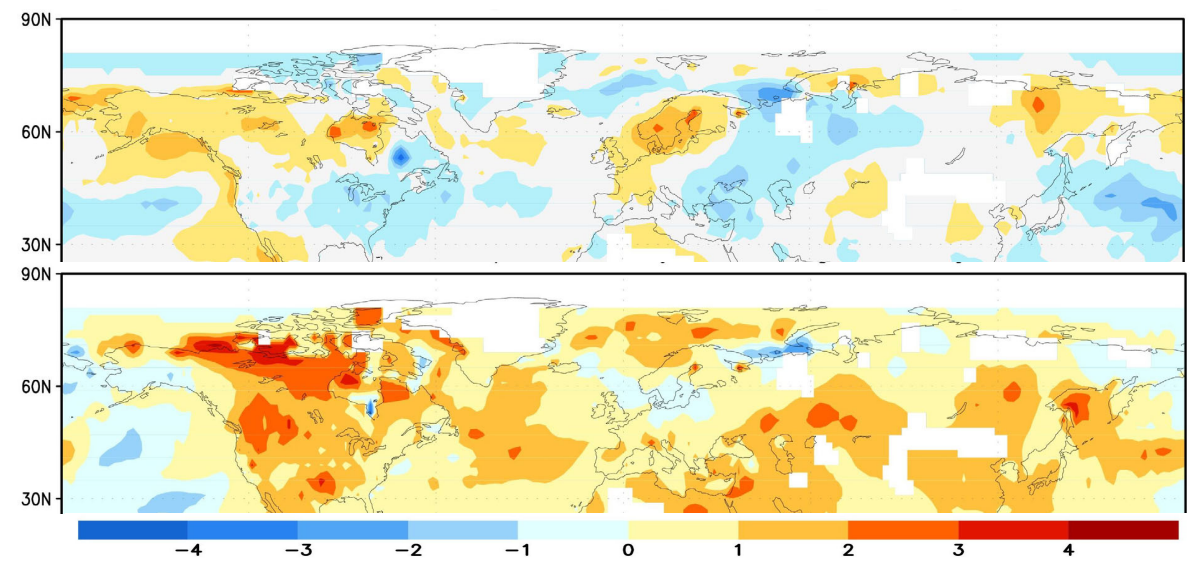

Fig. 1. Climatological surface temperature anomaly [K] from June to August of 1997 (top) and 1998 (bottom), according to NCEP reanalysis data.

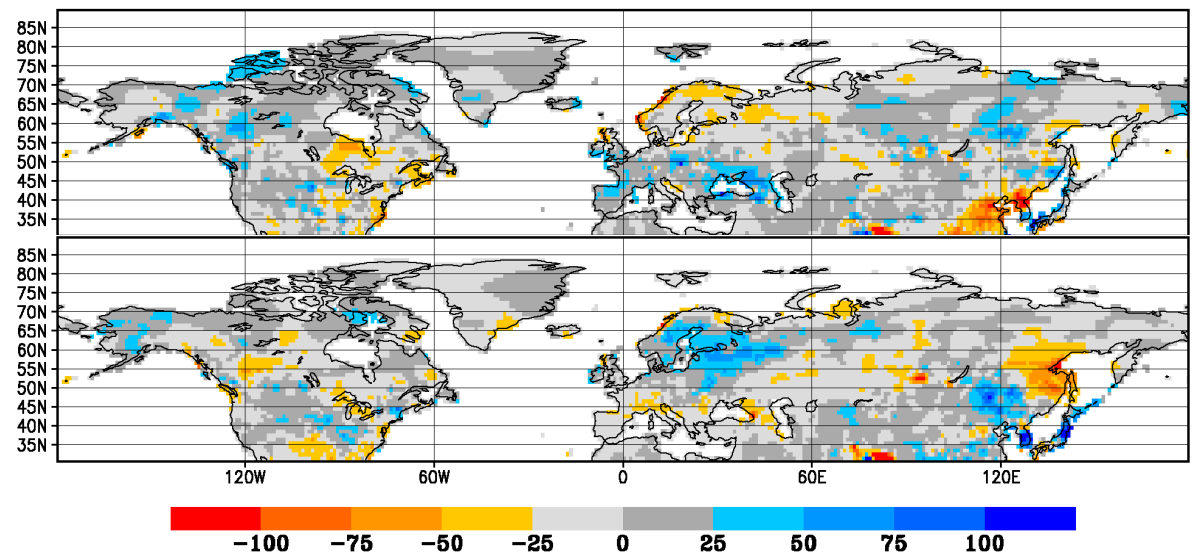

Fig. 2. Precipitation anomaly [mm/month] from June to August of 1997 (top) and 1998 (bottom), according to GPCC (Global Precipitation Climatology Centre) data.

(UNECE, 1999) (Table 1). Official data from UNECE (1999) suggest similarly large areas burned in Canada and Siberia in 1998 (Table 1). But Kasischke and Bruhwiler (2003) estimated that $29 \%$ of the total area was burned in Canada and $71 \%$ in Siberia. Unfortunately, more detailed fire inventories are not available, especially not for Siberia.

Therefore, night-time fire hot spots, based on data from the ATSR instrument flying on the ERS-2 platform (see http://shark1.esrin.esa.it/ionia/FIRE/), were used for characterizing the spatial distribution of the fires. Coordinates of hot spot locations are available on a daily basis for the period 1997 to 2001 and their total numbers are shown in Table 2. There is a high variation of the number of hot spots detected during the different years. 1997 has a below-average occurrence of hot spots, especially in Canada, whereas 1998 stands out as the year with most hot spot detections both in Canada and Siberia. In 1997 (Fig. 3 top), hot spots were detected mainly in the United States of America, Europe and Southern
Asia, but in 1998 (Fig. 3 bottom) regions with high density of fire hot spots can be seen in Canada and Eastern Siberia. A distinct maximum of hot spot occurrence was located over the Russian Far East, whereas the rest of Russia experienced a moderate fire season (Conard et al., 2002). The Russian Far East always has a very high fire danger because of the recurrence of drought conditions, the regional meteorological and topographical situation and the abundance of combustible material (Efremov and Sheshukov, 2000). However, in 1998 the situation was extreme, due to the strong drought caused by the El Niño/Southern Oscillation (Generoso et al., 2003; Novelli et al., 2003).

The hot spot data cannot directly be used to estimate the areas burned, and therefore we have to use other sources for this information. The ratio between Siberian and Canadian ATSR hot spot counts in 1998 is around 2.5 (see Table 2) in good agreement with the burned area estimation of Kasischke and Bruhwiler (2003). In order to obtain the same ratio 


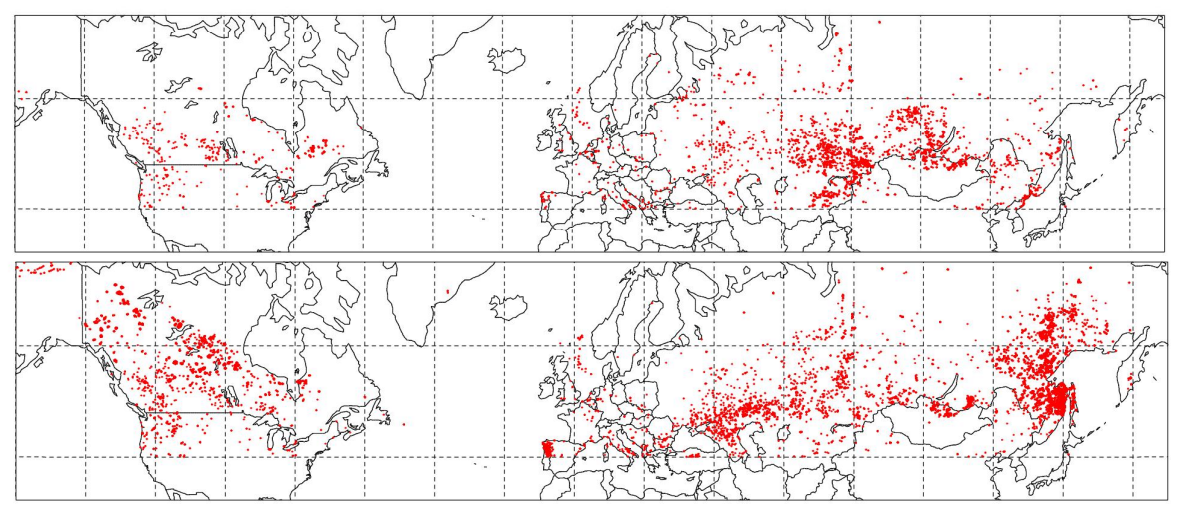

Fig. 3. ATSR hot spots summed from May to October of 1997 (top) and 1998 (bottom).

Table 3. Emitted masses of $\mathrm{CO}[\mathrm{Tg}]$ derived from the FLEXPART model setup.

\begin{tabular}{ccccc}
\hline & \multicolumn{2}{c}{ Siberia } & \multicolumn{2}{c}{ Canada } \\
& 1997 & 1998 & 1997 & 1998 \\
\hline May & 2.45 & 3.37 & 0.25 & 2.07 \\
June & 1.31 & 2.85 & 1.27 & 1.12 \\
July & 0.79 & 13.28 & 0.26 & 7.01 \\
Aug & 1.04 & 21.51 & 0.34 & 8.77 \\
Sep & 1.55 & 11.10 & 0.29 & 1.96 \\
Oct & 2.52 & 1.21 & 0.37 & 0.52 \\
\hline total & 9.68 & 53.68 & 2.78 & 21.45 \\
\hline
\end{tabular}

between Canadian and Siberian burned areas the official estimate (UNECE, 1999) for the total burned area in Canada was multiplied by a factor of 2.5 . Therefore for the simulation of the burning period of 1998 4.7 Mha and 11.7 Mha burned area were assumed for Canada and Siberia, respectively. Using the estimates of total area burned and the number of hot spots detected in 1997 and 1998, we estimate that, on average, a hot spot covered an area of 380 ha in 1997 and 540 ha in 1998. Although the actual areas burned may vary considerably from hot spot to hot spot, assuming that they all burned equal areas, we can use the hot spot data to determine the temporal and spatial variation of the burning, which were needed for the emission estimates. Because of the biases of satellite detection due to, e.g. cloud cover and smoke (Kasischke et al., 2003), the burned areas we use are rough assumptions.

In our model simulations we used a CO tracer to study the prevailing transport patterns and thus needed an estimate for the $\mathrm{CO}$ emissions. Emission factors for $\mathrm{CO}$ are normally based on the amount of biomass burned. For instance, Andreae et al. (2001) estimate $107 \mathrm{~g} \mathrm{CO} / \mathrm{kg}$ biomass burned. In order to apply this emission factor, we need to know the amount of biomass burned. Cofer et al. (1998) report fuel consumption rates for boreal forest fires of $4.27 \mathrm{~kg} / \mathrm{m}^{2}$. Using this rate together with our previous estimates of the areas burned, we can determine the emission rates of trace gases. Table 3 shows the monthly variation of the estimated CO emissions for both Siberia and Canada in 1997 and 1998 based on this algorithm. Total CO emissions of Canada and Siberia were estimated as around $75 \mathrm{Tg}$ in 1998 and about $12 \mathrm{Tg}$ in 1997. Compared to Canada's anthropogenic CO emissions of $52.7 \mathrm{Tg} / \mathrm{y}$ (see EDGAR emission inventory (1995), http://arch.rivm.nl/env/int/coredata/edgar/) Siberian CO emissions by fires in 1998 are around equal.

Our estimates of the $\mathrm{CO}$ emissions (see Table 3) are in good agreement with those of Kasischke and Bruhwiler (2003) and Duncan et al. (2003) who estimated that 88$102 \mathrm{Tg}$ and $70 \mathrm{Tg}$, respectively, of $\mathrm{CO}$ were emitted in the boreal region in the year 1998, and with the values given by Kajii et al. (2002), who calculated that $50 \mathrm{Tg} \mathrm{CO}$ were emitted in Siberia, in 1998. Finally, Novelli et al. (2003) calculated emissions of $300 \mathrm{Tg} \mathrm{CO}$ by all fires (including fires in the tropics) that burned during the El Niño in 1997/1998. Thus, based on our assumption of $75 \mathrm{Tg} \mathrm{CO}$ the boreal region contributed a substantial fraction, $25 \%$, to the total fire emissions in 1997/1998. Compared to the averaged global $\mathrm{CO}$ emissions by biomass burning of $748 \mathrm{Tg} / \mathrm{a}$ estimated by Holloway et al. (2000) and Galanter et al. (2000), the boreal region accounted for about 10\% in 1998 and 1.6\% in 1997.

\section{Data and Methodology}

The transport of forest fire emissions was simulated with the Lagrangian particle dispersion model FLEXPART (version 5.1) (Stohl et al. 1998,http://www.forst.tu-muenchen.de/ EXT/LST/METEO/stohl/) for the burning seasons of 1997 and 1998 from May to October. For this study, FLEXPART was used with northern hemispheric data from the European Centre for Medium-Range Weather Forecasts (ECMWF, $1995)$ with a horizontal resolution of $1 \times 1$ degree, 31 vertical levels and a time resolution of $3 \mathrm{~h}$ (analyses at $0,6,12$, 

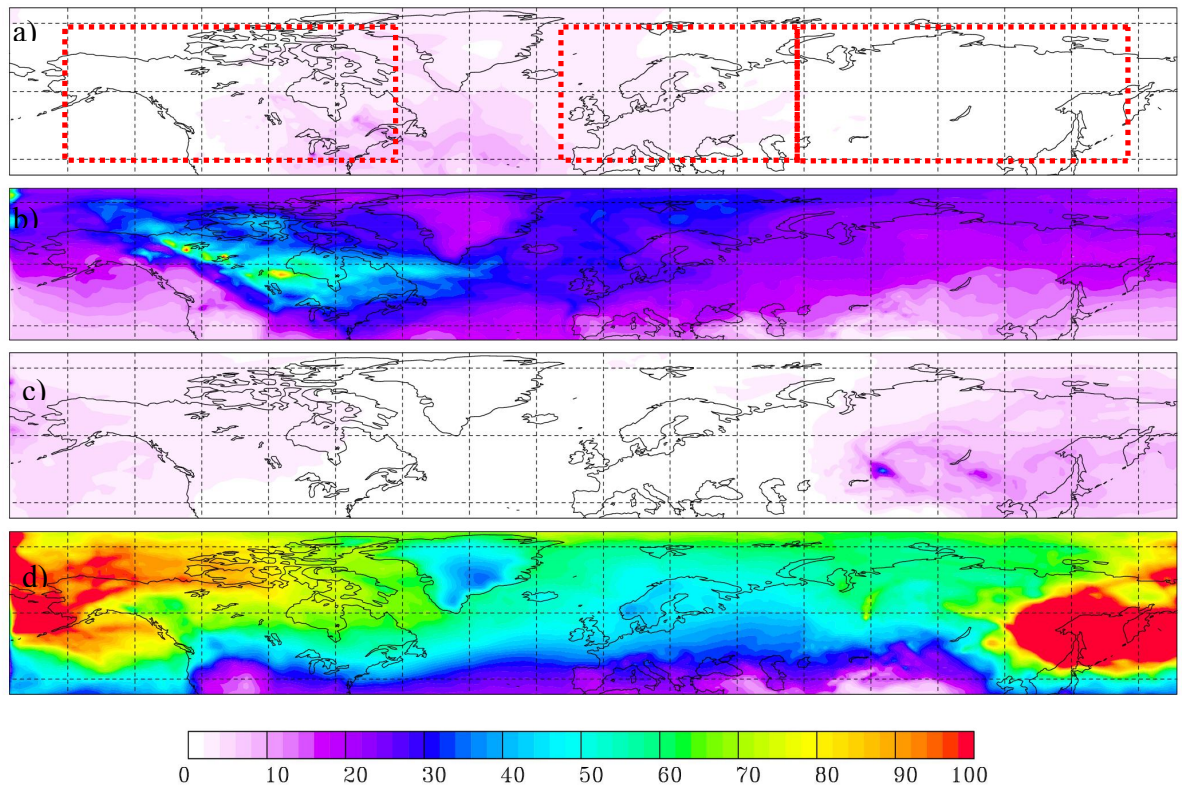

Fig. 4. Total columns of FLEXPART CO tracers $\left[\mathrm{mg} / \mathrm{m}^{2}\right]$ averaged from May to October: (a) Canadian CO tracer (1997), (b) Canadian CO tracer (1998), (c) Siberian CO tracer (1997) and (d) Siberian CO tracer (1998). The red boxes in panel (a) show the regions used for calculating source-receptor-relationships (see text for more details).

18 UTC; 3-hour forecasts at 3, 9, 15, 21 UTC). FLEXPART calculates the trajectories of a multitude of particles to simulate the transport of passive tracers. We simulated tracers for $\mathrm{CO}$ emitted by boreal forest fires, which were released according to our emission estimates (see Sect. 2), but for which deposition and chemical processes were considered only by applying a constant chemical lifetime of 60 days for the $\mathrm{CO}$ tracers. The lifetime of the $\mathrm{CO}$ tracer is assumed as a mean of the global lifetime of $\mathrm{CO}$ which is given by Seinfeld and Pandis (1998) within the range of 30 to 90 days. Independent $\mathrm{CO}$ tracers were used for Canadian and Siberian forest fires (according to Canadian and Siberian box shown in Fig. 4a), in order to distinguish between these two sources. CO emissions were put into the lowest $3 \mathrm{~km}$ of the model atmosphere. In order to see whether the simulated forest fire plumes appear also in observations, NOAA CMDL flask data, TOMS aerosol index data and GOME tropospheric $\mathrm{NO}_{2}$ and $\mathrm{HCHO}$ columns were inspected.

The NOAA CMDL Carbon Cycle Greenhouse Gases group makes measurements of $\mathrm{CO}_{2}$ and $\mathrm{CO}$. These measurements form a global network of background sites for carbon cycle monitoring (Novelli et al., 2003; Randerson et al., 1999), which measure continuously since the end of the 1970s. $\mathrm{CO}_{2}$ data are available since 1982 and $\mathrm{CO}$ data since 1990.

The TOMS instrument on board the Earth Probe satellite (for further details, see http://toms.gsfc.nasa.gov/) provides data on UV-absorbing tropospheric aerosols, including dust, volcanic ash and smoke from biomass burning. Absorbing particles are determined by a differencing method, which is more sensitive for UV-absorbing aerosols than for nonabsorbing aerosols like clouds and sulfur particles (Hsu et al., 1996). Forest fires, desert dust, volcanic ash and anthropogenic sources all create absorbing particles, but in highlatitude regions forest fires are the main source of these particles in summer.

GOME tropospheric $\mathrm{NO}_{2}$ column densities are used to see whether boreal forest fires are a significant source of $\mathrm{NO}_{\mathrm{x}}$. Spichtinger et al. (2001) have found strong enhancements of $\mathrm{NO}_{2}$ above a fire burning in Canada in 1998, but it is important to clarify whether boreal forest fires can also create $\mathrm{NO}_{2}$ anomalies on a seasonal basis. The tropospheric $\mathrm{NO}_{2}$ columns are supplemented by tropospheric HCHO columns, because $\mathrm{HCHO}$ is a primary emission product from biomass burning (Carlier et al., 1986; Lipari et al., 1984). Maps of tropospheric $\mathrm{NO}_{2}$ columns and tropospheric $\mathrm{HCHO}$ columns were derived from spectroscopic data from the GOME instrument on board the ERS-2 satellite, which was launched into a polar sun-synchronous orbit in April 1995. Raw spectral data undergo several processing steps, as described in Beirle et al. (2003), to obtain tropospheric $\mathrm{NO}_{2}$ columns. Basically, differential optical absorption spectroscopy (DOAS) is used to produce total vertical $\mathrm{NO}_{2}$ column densities, from which an estimate of the stratospheric portion is subtracted. HCHO slant columns are also determined from GOME spectra by using algorithms developed at the IUP Heidelberg, with basically the same DOAS retrieval method as used for the HCHO ground measurements (Wagner et al., 2004). In contrast to $\mathrm{NO}_{2}$, the stratospheric $\mathrm{HCHO}$ can be neglected. Thus, the retrieved slant columns directly represent 
Table 4. Source-receptor relationships for boreal forest fire emissions.

\begin{tabular}{cccc}
\hline Source & Receptor & $\begin{array}{c}\text { Avg. column dens. } \\
{\left[\mathrm{mg} / \mathrm{m}^{2}(\%)^{1}\right]}\end{array}$ & $\begin{array}{c}\text { Avg. surface } \\
\text { mix. ratio [ppb] }\end{array}$ \\
\hline & 1997 & $\mathrm{CO}$ & \\
\hline Russia & Canada & $2.7(18)$ & 0.3 \\
Russia & Russia & $6.2(37)$ & 0.5 \\
Canada & Europe & $2.1(11)$ & 0.1 \\
Canada & Canada & $2.3(28)$ & 0.2 \\
\hline & \multirow{2}{*}{1998} & $\mathrm{CO}$ & \\
\hline Russia & Canada & $69(26)$ & 7.4 \\
Russia & Russia & $91(22)$ & 2.3 \\
Canada & Europe & $24(13)$ & 2.4 \\
Canada & Canada & $29(32)$ & \\
\hline
\end{tabular}

Percentage of FLEXPART total emitted mass ${ }^{1}$.

the tropospheric HCHO. However, we applied an offset correction to account for GOME degradation effects for each latitude: the slant column densities over oceans, supposed to be zero, have been subtracted to normalize the HCHO slant columns. With a ground pixel size of $40 \times 320 \mathrm{~km}^{2}$ GOME data have a global coverage at the equator every 3 days, but better time resolution in polar regions.

\section{Transport Modelling}

In order to evaluate the dominating transport patterns of boreal forest fire emissions on a seasonal basis, the FLEXPART model results for the Siberian and Canadian CO tracers were averaged over the burning seasons of 1997 and 1998. Figure 4 shows the total columns of the $\mathrm{CO}$ tracers for the Canadian and Siberian tracers during the burning seasons of the two years. Due to the fewer fires in 1997 simulated CO columns are lower than in 1998. In both years the largest $\mathrm{CO}$ tracer columns are found directly over the source regions, but significant transport to downwind regions occurs. The Canadian fire plume moves eastward across the Atlantic ocean towards Europe. Siberian fire emissions take a pathway eastwards across the Northern Pacific towards Canada. Taking this pathway, the fire plume also travels over northern Japan, where in 1998 Japanese surface CO measurements showed a maximum difference of about $30 \mathrm{ppb}$ between air masses which have and those which have not passed the 1998 Siberian fires according to trajectory analyses (Kato et al., 2002). Additionally, Tanimoto et al. (2000) found baseline enhancements and episodic high concentrations of $\mathrm{CO}$ at the measurement site of Rishiri, Japan, during the boreal burning season of 1998. To estimate the extent of intercontinental transport of the forest fire emissions, the relative $\mathrm{CO}$ tracer amounts remaining close to the source and reaching another continent were calculated by defining three boxes for the latitude band $40^{\circ}-80^{\circ} \mathrm{N}$ : Canada $\left(160^{\circ}-60^{\circ} \mathrm{W}\right)$, Europe $\left(10^{\circ} \mathrm{W}-60^{\circ} \mathrm{E}\right)$ and Siberia $\left(60^{\circ}-140^{\circ} \mathrm{E}\right)$ (see Fig. 4a). As shown in Table 4, a larger fraction of the Russian forest fire emissions was transported to Canada in 1998 than in 1997. This is due to the special meteorological situation during the burning season of 1998, when the abnormally persistent high pressure system east of Siberia (Efremov and Sheshukov, 2000) channeled pollution across the northern Pacific. In 1998, the average column densities of the Siberian tracer are more than twice as high as the Canadian tracer columns in the Canadian receptor box. At the surface in the Canadian receptor box the Siberian tracer mixing ratio is $6.8 \mathrm{ppb}$ on average (see Table 4 and Fig. 6). Especially at the Canadian west coast, transport from Siberia provided the dominant fraction of the CO tracer (Fig. 4d).

The Canadian CO tracer was transported to similar fractions in both years. But, at the surface the Canadian tracer plume is shifted to the south compared to the total columns (Figs. 6 and 4b), due to the prevailing low-level flows in subtropical latitudes, as compared to the frontal lifting that typically accompanies poleward transport (Stohl, 2001). Canadian forest fire emissions contributed $2.3 \mathrm{ppb}$ of $\mathrm{CO}$ to the average European CO surface mixing ratios in 1998. These intercontinental transport processes are documented in more detail in Fig. 5. Meridionally oriented vertical cross sections of zonal means of the forest fire $\mathrm{CO}$ tracers for each of the above defined boxes are shown for 1997 and 1998. In all receptor boxes the maxima of all tracers appear at an altitude range from about 2 to $6 \mathrm{~km}$. The highest concentrations of the Siberian tracer over the source region are found at latitudes up to $70^{\circ} \mathrm{N}$ in both years. Over Canada the Siberian plume is, on average, found at higher altitudes than over the Siberian source region. The Canadian tracer extends to higher latitudes over the source, in 1998 it reached $80^{\circ} \mathrm{N}$. Significant differences in the plume positions over Europe are found between the two years. Both tracers arrive at higher latitudes in 1998 than in 1997, which is due to a higher NAO index in 1998 than in 1997, which shifts the North Atlantic stormtrack and, thus, the dominant transport pathway to the north (Eckhardt et al., 2003). In general, drought conditions in parts of the boreal region, which were likely induced by ENSO, caused extensive burning in 1998 with a maximum in the far east of Siberia near the coast of the Okhotsk Sea. From there the emissions are directly subjected to the westerly flow. This is in contrast to 1997, when the hot spots were situated much more westerly in continental regions of Siberia. Furthermore, transport pathways are shifted northwards according to the positive phase of NAO. This produces a shift of the tracer distribution towards higher latitudes in 1998 compared to 1997. 

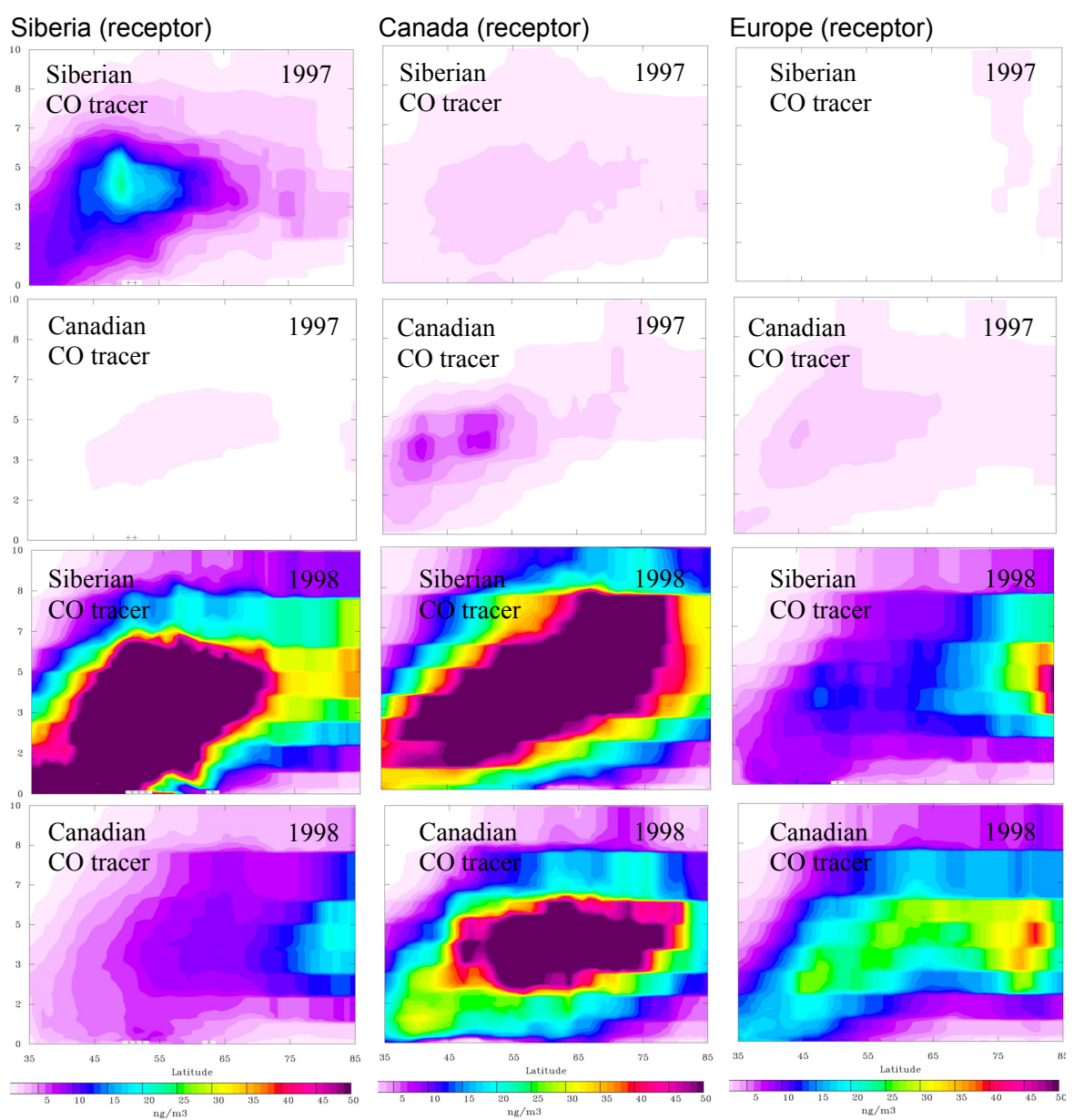

Fig. 5. Vertical cross sections of zonal means of the averaged CO tracer concentrations for the three receptor regions (see Fig.4). Siberia (left column), Canada (middle column) and Europe (right column). The rows from top to bottom show the Siberian CO tracer in 1997, the Canadian CO tracer in 1997, the Siberian CO tracer in 1998 and the Canadian CO tracer in 1998 against altitude [km].
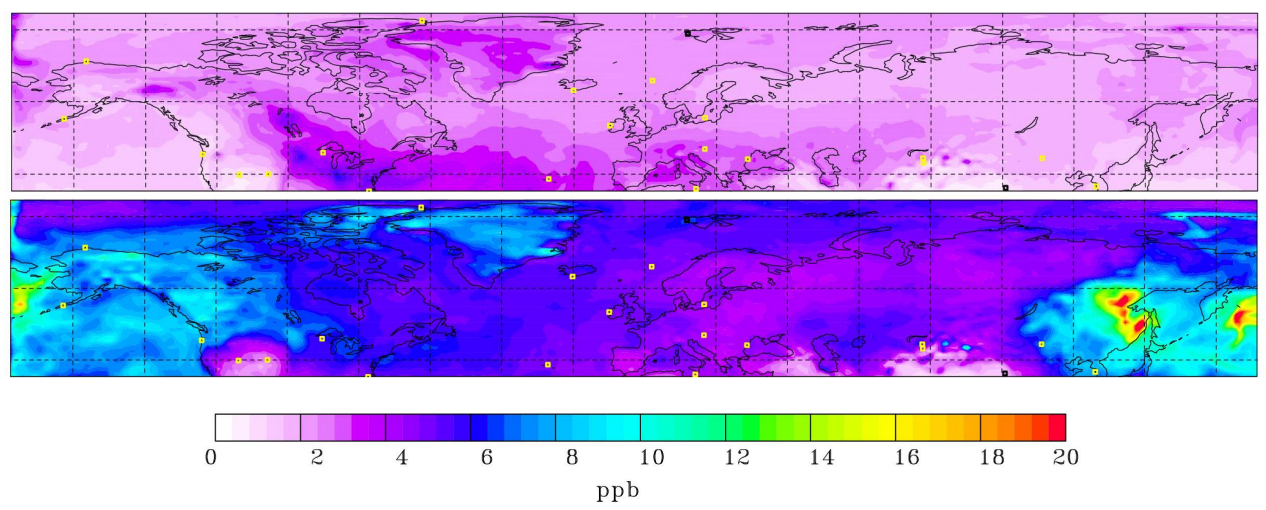

Fig. 6. FLEXPART mixing ratios at the lowest model layer in 1998; Canadian CO tracer (top), Siberian CO tracer (bottom); CMDL stations are marked as yellow squares 


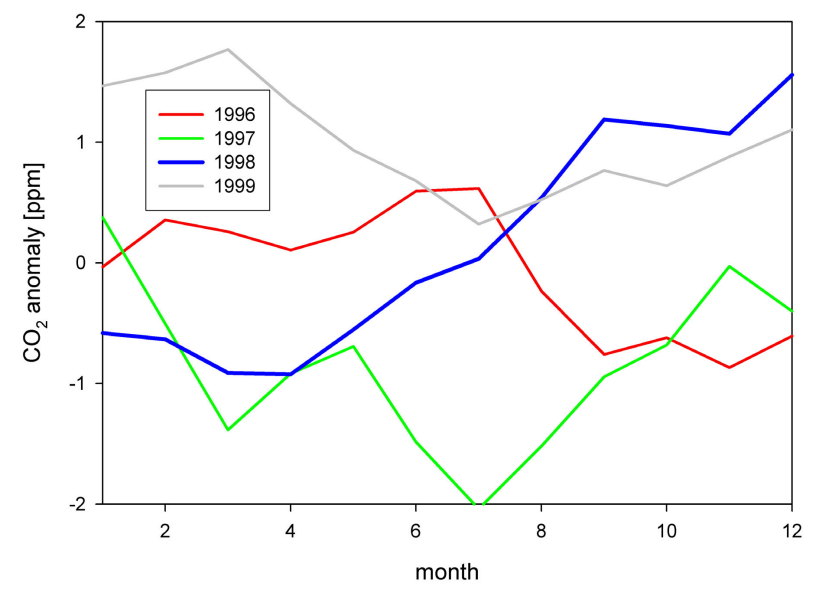

Fig. 7. Seasonal variation of the detrended anomalies [ppm] of $\mathrm{CO}_{2}$ averaged over all CMDL stations north of $35^{\circ} \mathrm{N}$.

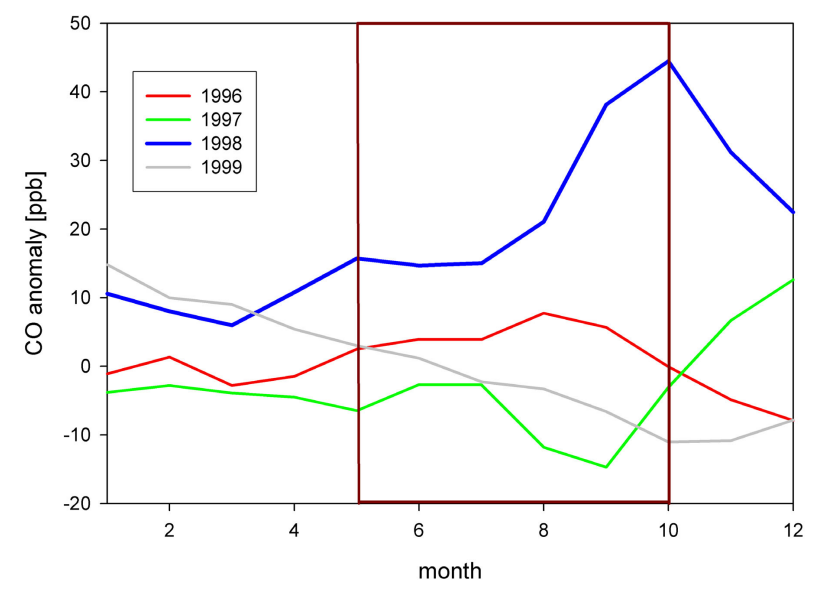

Fig. 8. Seasonal variation of the detrended anomalies (ppb) of $\mathrm{CO}$ averaged over all CMDL stations north of $35^{\circ} \mathrm{N}$; the dark red rectangle reflects the burning season from May to October, which is shown in Fig. 9

\section{Ground Based Measurements and Satellite Remote Sensing Results for the Burning Seasons 1997 and 1998}

Around $90 \%$ of carbonaceous emissions from forest fires are $\mathrm{CO}_{2}$. Ground based measurements of $\mathrm{CO}_{2}$ and $\mathrm{CO}$ are available continuously since 1982 and 1990, respectively, from the CMDL flask network. To find a signal from the boreal forest fires in these data, monthly means were calculated for all stations located north of $35^{\circ} \mathrm{N} . \mathrm{CO}_{2}$ concentrations are increasing due to continuing anthropogenic $\mathrm{CO}_{2}$ emissions, whereas $\mathrm{CO}$ concentrations are decreasing, because of reduced anthropogenic CO emissions (Wotawa et al., 2001; Novelli et al., 2003). In order to remove these trends, the monthly mean $\mathrm{CO}_{2}$ and $\mathrm{CO}$ data were detrended using a linear regression function. Monthly anomalies of the detrended

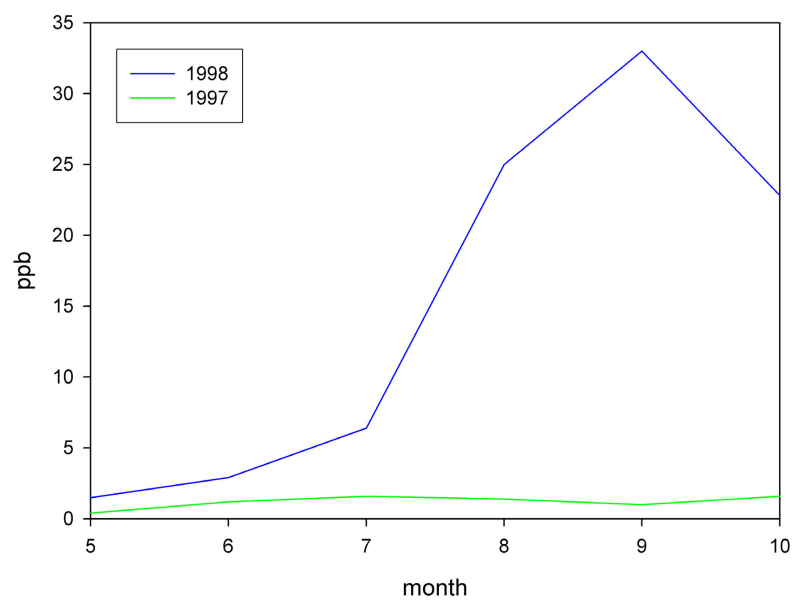

Fig. 9. Monthly mean FLEXPART CO tracer mixing ratios averaged for the positions of the CMDL stations.

CMDL data for both species for the years 1996 to 1999 are shown in Fig. 7 and 8. In 1997 the $\mathrm{CO}_{2}$ anomalies were negative during most of the year, indicating less than normal fire activity. In contrast, in 1998 they increased rapidly from May on, when the burning season started. The $\mathrm{CO}_{2}$ anomaly peaked at $1.2 \mathrm{ppm}$ in September, after the strongest burning was over. But because of the long lifetime (much longer than 1 year (Seinfeld and Pandis, 1998)) of $\mathrm{CO}_{2}$, the $\mathrm{CO}_{2}$ anomalies remained elevated until April 1999, when the $\mathrm{CO}_{2}$ pulse from the fires was sufficiently diluted by mixing into the tropics and the southern hemisphere. Furthermore, because of increased soil temperatures the flux of $\mathrm{CO}_{2}$ and other trace gases out of the soils may persist even after the fires are extinguished (Kim and Tanaka, 2003).

Because of the shorter lifetime of $\mathrm{CO}$ (30 to 90 days) compared to $\mathrm{CO}_{2}$, monthly $\mathrm{CO}$ anomalies for 1998 give a slightly different picture (Fig. 8), tracking the temporal variations of the burning more closely. There is a first peak in the CO anomalies in May 1998, followed by a slight decrease in June and July burned, and a sharp increase into September and October, caused by the strong boreal burning from the middle of July until October. After negative $\mathrm{CO}$ anomalies during most of the 1997 burning season, CO started increasing in September 1997 when strong burning in Southeast Asia occurred. The positive CO anomaly in May 1998, was likely to be caused by northward transport of emissions from the subtropics. For instance, Van der Werf et al. (2004) assume a contribution of tropical fires to boreal $\mathrm{CO}$ amounts of around $26 \%$. In October, the $\mathrm{CO}$ anomaly was $44 \mathrm{ppb}$, a substantial fraction of the detrended $\mathrm{CO}$ value of around $115 \mathrm{ppb}$ for that month. This indicates that forest fires were a major contributor to the CO budget in the summer of 1998, in agreement with previous studies (Wotawa et al., 2001; Novelli et al., 2003). In contrast, CO anomalies for the summer of 1997 were all negative, most strongly at the end of the burning season in September. 

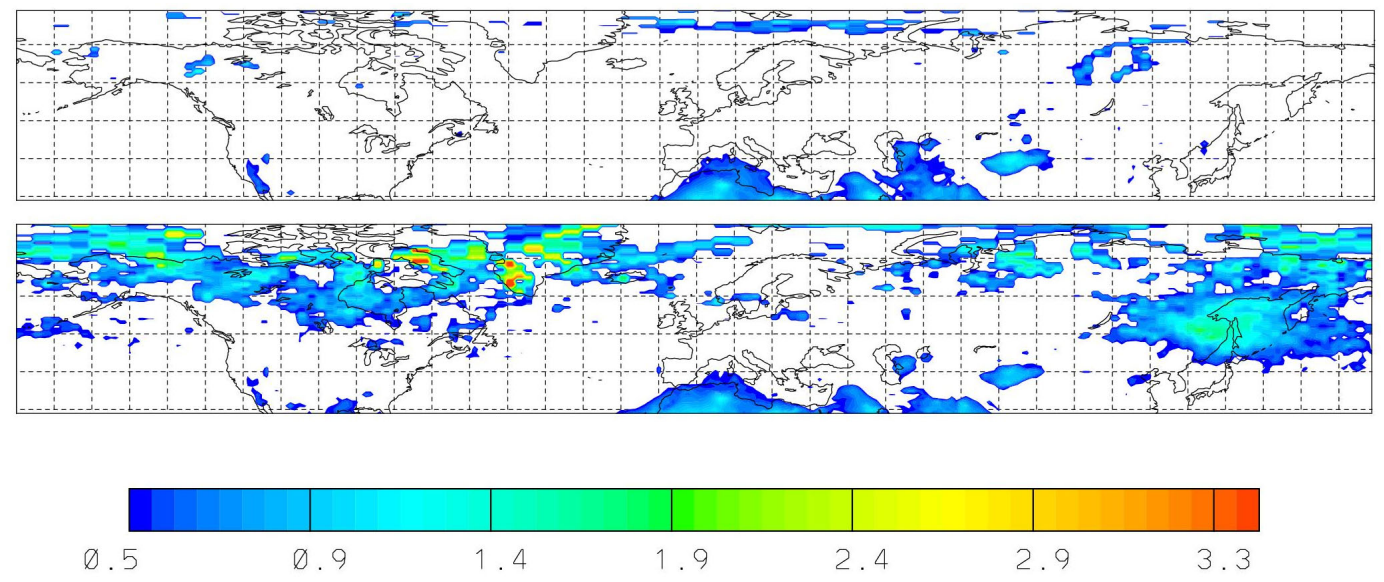

Fig. 10. TOMS aerosol index averaged from May to October 1997 (top) and 1998 (bottom).

To compare the model results with the $\mathrm{CO}$ measurements, modelled monthly mean surface layer $\mathrm{CO}$ mixing ratios were averaged for the locations of the CMDL stations marked in Fig. 6. The sum of the surface CO tracers for both sources, Canada and Siberia are shown in Fig. 9 (the simulation was started with the estimated emissions shown in Table 3). FLEXPART CO tracers give a similar picture as the CMDL $\mathrm{CO}$ measurements (Fig. 8), with a strong increase starting in July 1998 and extremely low CO mixing ratios in 1997. The FLEXPART simulation shows the maximum CO enhancement of $33 \mathrm{ppb}$ (above the background) already in September 1998, one month earlier than the measurements. This may be due to the rather short 60-day lifetime we have assumed in our simulations. The maximum would be delayed by using a longer lifetime or a seasonally increasing lifetime. Furthermore, as mentioned previously, $\mathrm{CO}$ emissions may persist even after the above-ground fires are extinguished and no hot spots are detected anymore. Such continuing emissions are not accounted for in our simulations. However, the comparison between Fig. 8 and 9 shows that the assumed emissions and their seasonal variation is in good general agreement. The underestimation of the $\mathrm{CO}$ measurement data by the FLEXPART model simulation amounts around $25 \%$, which is comparable to the contribution of tropical fire emissions to boreal CO concentrations, mentioned by Van der Werf et al. (2004). Figure 10 shows the average TOMS AI for the burning seasons of 1997 and 1998, respectively. In both years the enhancements due to Saharan dust can be seen at low latitudes. During 1997 there are relatively few enhancements of the AI over the boreal region. In contrast, in 1998 a large maximum over Canada and the neighbouring oceanic regions and a further maximum over eastern Siberia and the bordering Pacific are found. The maxima over Canada and Siberia are in magnitude comparable to the extended biomass burning regions of Central Africa. The areas of enhanced AI spread in a wavely band over Canada, are more concentrated over eastern Siberia and join over the northern Pacific re- gion. On the one hand TOMS measurements show the broad region affected by the aerosols emitted from the fires of 1998 and on the other hand aerosols detected over the oceans give a clear proof for atmospheric transport of fire emissions. The general patterns confirm the model simulations (Fig. 4).

Figure 11 shows maps of tropospheric $\mathrm{NO}_{2}$ and $\mathrm{HCHO}$ columns derived from GOME, (averaged from July to August) for 1997 and 1998. Beside the high values over the industrial regions of USA, Europe, Middle East and Asia, relatively large enhancements can be seen over Southeast Siberia in 1998 compared to 1997, when the burning was most intense (see circle in Fig. 11). The enhanced biomass burning over southeast Siberia in 1998 can also be well identified and correlated with a high $\mathrm{HCHO}$ plume. The high $\mathrm{HCHO}$ columns over eastern USA are due to biogenic isoprene emissions (Chance et al., 2000). In consideration of the variance of forest fire emissions in contrast to the continuity of anthropogenic $\mathrm{NO}_{2}$ emissions, the GOME signal over Eastern Siberia reveals the strength of this emission source in 1998. Although $\mathrm{NO}_{2}$ enhancements over fires are occasionally also seen over Canada (compare Spichtinger et al., 2001), on a seasonal basis the enhancements are far less pronounced than over Siberia. This is probably due to the smaller areas burned and the more widespread distribution of fires in Canada (see Fig. 3).

\section{Summary and conclusions}

In this study we compared the boreal burning seasons of 1997 and 1998. According to burned area statistics fire activity was relatively low and atmospheric effects were moderate in 1997 compared to 1998 . In 1998 the boreal region, particularly in Canada and southeastern Siberia, suffered from a severe drought and high temperatures, both of which favoured the occurrence of forest fires. Temperature anomalies up to $4.5 \mathrm{~K}$ above the climatological average were found in the regions where most of the burning occurred. 

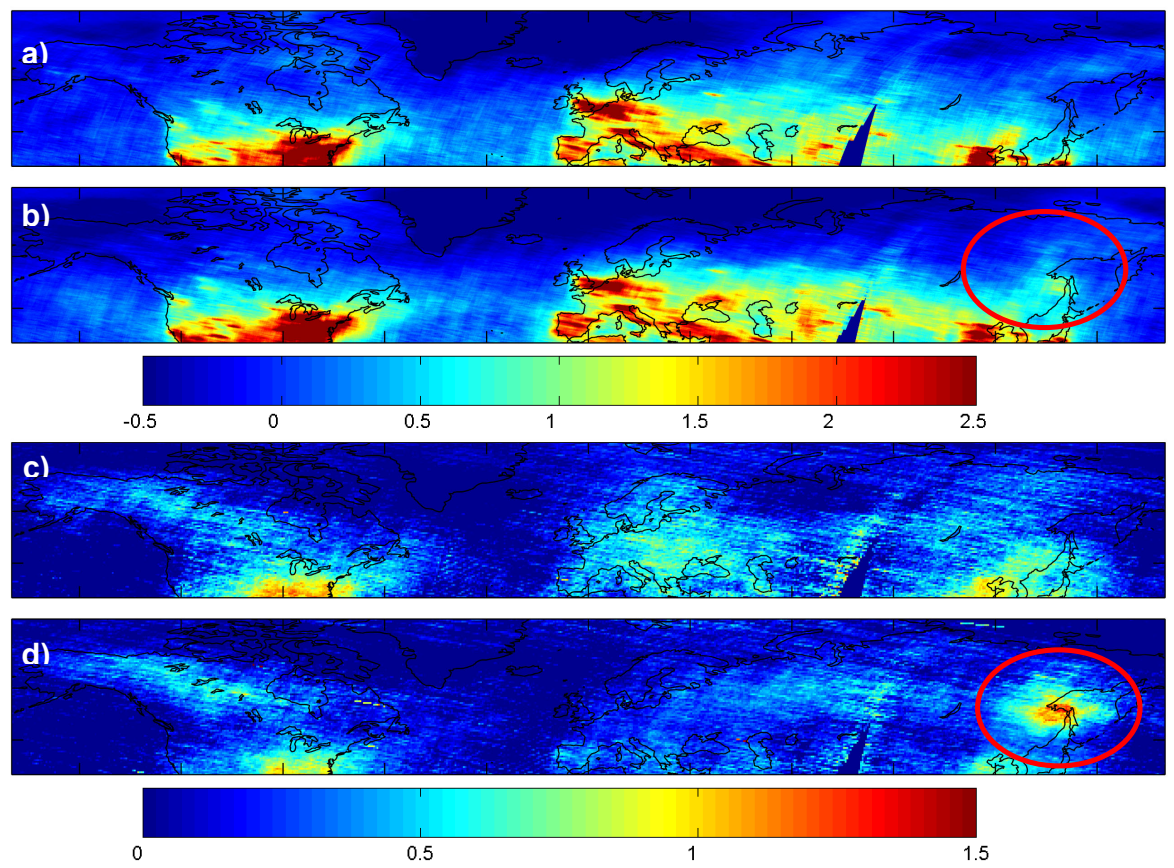

Fig. 11. GOME tropospheric $\mathrm{NO}_{2}\left[10^{15}\right.$ molecules $\left./ \mathrm{cm}^{2}\right]$ and $\mathrm{HCHO}\left[10^{16}\right.$ molecules $\left./ \mathrm{cm}^{2}\right]$ columns averaged from July to August 1997 (a for $\mathrm{NO}_{2}$ and $\mathbf{c}$ for $\mathrm{HCHO}$ ) and 1998 (b for $\mathrm{NO}_{2}$ and $\mathbf{d}$ for $\mathrm{HCHO}$ ). The red circle marks enhanced $\mathrm{NO}_{2}$ and $\mathrm{HCHO}_{\mathrm{C}}$ columns over eastern Siberia where the strongest fire activity occurred in 1998.

These anomalies were likely a consequence of the strong ENSO event of 1997/1998. We simulated the atmospheric transport of the emissions from the burning during the fire seasons of 1997 and 1998 with a Lagrangian transport model using $\mathrm{CO}$ as a tracer. Forest fire emissions were released at the ATSR hot spot locations. To quantify the transport of the forest fire emissions the modelled fire plumes were split into a Canadian, a European and a Siberian sector. FLEXPART results were compared to measurement data of $\mathrm{CO}_{2}$ and $\mathrm{CO}$. The influence of burning on these two species can be seen in surface measurements of the CMDL flask sampling network. Strong positive anomalies of both species in 1998 are in contrast to negative anomalies in 1997. Forest fires emit large amounts of aerosols which are detected by TOMS AI. The signal of the GOME instrument measuring tropospheric $\mathrm{NO}_{2}$ and $\mathrm{HCHO}$ columns is not as clear as the TOMS one, but there is enhanced $\mathrm{NO}_{2}$ and $\mathrm{HCHO}$ over the strongest burning region of Southeast Siberia.

The main conclusions of this study are:

- The transport simulation shows intercontinental transport of $\mathrm{CO}$ emitted by forest fires. Likely induced by ENSO, in 1998 a larger fraction of forest fire CO was transported from Siberia towards Canada, contributing more than twice as high concentrations as Canada's own biomass burning CO. In 1998 both tracers arrived at higher latitudes over Europe than in 1997, consistent with a higher NAO index in 1998.
- The interannual variability of fire activity in the boreal region could clearly be seen in ground based measurements of $\mathrm{CO}$ and $\mathrm{CO}_{2}$ as well as in satellite data of the TOMS and the GOME instruments.

- Monthly variations of CMDL CO data are reproduced by the FLEXPART model simulation. The maximum anomaly of the $\mathrm{CO}$ measurements was $44 \mathrm{ppb}$ in October 1998, the maximum CO mixing ratio calculated with FLEXPART for the lowest model layer was $33 \mathrm{ppb}$ in September 1998. The delay of the maximum is attributed to the relatively short lifetime of $\mathrm{CO}$ (60 days) which was used for the FLEXPART setup.

- TOMS data show expanded maxima over Eastern Siberia and Canada. The aerosol clouds swap from the source regions across the oceans to the neighbouring continents, what reflects transport processes of aerosols, which look very similar than tracer plumes simulated by FLEXPART.

- GOME data show relatively large $\mathrm{NO}_{2}$ and $\mathrm{HCHO}$ enhancements over the burning regions of eastern Siberia in 1998, but no distinct maximum over the Canadian fire regions which were dispersed over a wider latitude range.

- Model simulations and measurement data revealed a strong impact of boreal forest fire emissions on the atmospheric composition of the northern higher latitudes in 1998. 
Acknowledgements. This study was funded by the German Ministry for Education and Research as part of the NOXTRAM project (Atmospheric Research 2000) and the PARTS Project. We thank the Deutscher Wetterdienst for kindly providing access to ECMWF and GPCC data. We appreciate the provision of data via the internet by NASA/GSFC and ATSR World Fire Atlas.

Edited by: D. Grainger

\section{References}

Amiro, B. D., Todd, J. B., Wotton, B. M., Logan, K. A., Flannigan, M. D., Stocks, B. J., Mason, J. A., Martell, D. L., and Hirsch, K. G.: Direct carbon emissions from Canadian forest fires, 19591999, Can. J. Forest Res., 31, 512-525, 2001.

Andreae, M. O., Artaxo, P., Fischer, H., Freitas, S. R., Grégoire, J.-M., Hansel, A., Hoor, P., Kormann, R., Krejci, R., Lange, L., Lelieveld, J., Lindinger, W., Longo, K., Peters, W., de Reus, M., Scheeren, B., Silva Dias, M. A. F., Ström, J., van Velthoven, P. F. J., and Williams, J.: Transport of biomass burning smoke to the upper troposphere by deep convection in the equatorial region, Geophys. Res. Lett., 28, 951-954, 2001.

Andreae, M. O. and Merlet, P.: Emission of trace gases and aerosols from biomass burning, Global Biogeochem. Cyc., 15, 955-966, 2001

Asakuma, K., Kuze, H., Takeuchi, N., and Yahagi, T.: Detection of biomass burning smoke in satellite images using texture analysis, Atmos. Env., 36, 1531-1542, 2002.

Beirle, S., Platt, U., Wenig, M., and Wagner, T.: Weekly cycle of NO2 by GOME measurements: a signature of anthropogenic sources, Atmos. Chem. Phys., 3, 2225-2232, 2003

Cahoon Jr., D. R., Stocks, B. J., Levine, J. S., Cofer III, W. R., and Pierson, J.: Satellite analysis of the severe 1987 forest fires in northern China and southeastern Siberia, J. Geophys. Res., 99, 18 627-18 638, 1994.

Carlier, P., Hannachi, H., and Mouvier, G.: The chemistry of carbonyl compounds in the atmosphere, Atmos. Env., 20, 20792099, 1986.

Chance, K., Palmer, P. I., Spurr, R. J. D., Martin, R. V., Kurosu, T. P., and Jacob, D. J.: Satellite observations of formaldehyde over North America from GOM, Geophys. Res. Lett., 27, 3461-3464, 2000.

Chan, C. Y., Chan, L. Y., Harris, J. M., Oltmans, S. J., Blake, D. R., Qin, Y., Zheng, Y. G., and Zheng, X. D.: Characteristics of biomass burning emission sources, transport, and chemical speciation in enhanced springtime tropospheric ozone profile over Hong Kong, J. Geophys. Res., 108, 4015, doi:10.1029/2001JD001555, 2003.

Cofer III, W. R., Winstead, E. L., Stocks, B. J., Goldammer, J. G., and Cahoon, D. R.: Crown fire emissions of $\mathrm{CO}_{2}, \mathrm{CO}, \mathrm{H}_{2}, \mathrm{CH}_{4}$, and TNMHC from a dense jack pine boreal forest fire, Geophys. Res. Lett., 25, 3919-3922, 1998.

Conard, S. G. and Ivanova, G. A.: Wildfire in Russian boreal forests-potential impacts on fire regime characteristics on emissions and global carbon balance estimates, Env. Pollut., 98, 305313, 1997

Conard, S. G., Sukhinin, A. I., Stocks, B. J., Cahoon, D. R., Davidenko, E. P., and Ivanova, G. A.: Determining effects of area burned and fire severity on carbon cycling and emissions in Siberia, Clim. Cange, 55, 197-211, 2002.

Crutzen, P. J. and Merlet, A.: Biomass burning in the Tropics: Impact on atmospheric chemistry and biogeochemical cycles, Science, 250, 1669-1678, 1990.

Duncan, B. N., Randall, M. V., Staudt, A. C., Yevich, R., and Logan, J. A.: Interannual and seasonal variability of biomass burning emissions constrained by satellite observations, J. Geophys. Res., 108, 4100, doi:10.1029/2002JD002378 2003

Eckhardt, S., Stohl, A., Beirle, S., Spichtinger, N., James, P., Forster, C., Junker, C., Wagner, T., Platt, U., and Jennings, S. G.: The North Atlantic Oscillation controls air pollution transport to the Arctic, Atmos. Chem. Phys., 3, 1769-1778, 2003.

Efremov, D. F. and Sheshukov, M. A.: Ecological and economic evaluation of the consequences of catastrophic fires in the Russian Far East: The Khabarovsk Territory Example of 1998, IFFN, 22, 53-62, 2000.

ECMWF: User Guide to ECMWF Products 2.1, Meteorological Bulletin M3.2, ECMWF, Reading, UK, 1995.

Flannigan, M. D., Bergeron, Y., Engelmark, O., and Wotton, B. M.: Future wildfire in circumboreal forests in relation to global warming, J. Vegetation Sci., 9, 469-476, 1998

Forster, C., Wandinger, U., Wotawa, G., James, P., Mattis, I., Althausen, D., Simmonds, P., O’Doherty, S., Jennings, S. G., Kleefeld, C., Schneider, J., Trickl, T., Kreipl, S., Jäger, H., and Stohl, A.: Transport of boreal forest fire emissions from Canada to Europe, J. Geophys. Res., 106, 22 887-22 906, 2001.

French, N. H. F., Kasischke, E. S., and Williams, D. G.: Variability in the emission of carbon-based trace gases from wildfire in the Alaskan boreal forest, J. Geophys. Res., 108, 8151, doi:10.1029/2001JD000480, 2003.

Fromm, M., Alfred, J., Hoppel, K., Hornstein, J., Bevilacqua, R., Shettle, E., Servranckx, R., Li, Z., and Stocks, B.: Observations of boreal forest fire smoke in the stratosphere by POAM III, SAGE II, and lidar in 1998, Geophys. Res. Lett., 27, 1407$1410,2000$.

Fromm, M. and Servranckx, R.: Transport of forest fire smoke above the tropopause by supercell convection, Geophys. Res. Lett, 1542, doi:10.1029/2002GL016820, 2003.

Galanter, M., Levy II, H., and Carmichael, G. R.: Impacts of biomass burning on tropospheric $\mathrm{CO}, \mathrm{NO}_{\mathrm{x}}$, and $\mathrm{O}_{3}$, J. Geophys. Res., 105, 6633-6653, 2000.

Generoso, S., Breon, F.-M., Balkanski, Y., Boucher, O., and Schulz, M.: Improving the seasonal cycle and interannual variations of biomass burning aerosol sources, Atmos. Chem. Phys., 3, 1211$1222,2003$.

Guzzi, R., Ballista, G., Di Nicolantonio, W., and Carboni, E. Aerosol maps from GOME data, Atmos. Env., 35, 5079-5091, 2001.

Holloway, T., Levy II, H., and Kasibhatla, P.: Global distribution of carbon monoxide, J. Geophys. Res., 105, 12 123-12 147, 2000.

Hsu, N. C., Herman, J. R., Bhartia, P. K., Seftor, C. J., Torres, O., Thompson, A. M., Gleason, J. F., Eck, T. F., and Holben, B. N.: Detection of biomass burning smoke from TOMS measurements, Geophys. Res. Lett., 23, 745-748, 1996.

Jaegle, L., Jacob, D. J., Wang, Y., Weinheimer, A. J., Ridley, B. A., Campos, T. L., Sachse, G. W., and Hagen, D. E.: Sources and chemistry of $\mathrm{NO}_{\mathrm{x}}$ in the upper troposphere over the United States, Geophys. Res. Lett., 25, 1709-1712, 1998. 
Kajii, Y., Kato, S., Streets, D. G., Tsai, N. Y., Shvidenko, A., Nilsson, S., McCallum, I., Minko, N. P., Abushenko, N., Altyntsev, D., and Khodzer, T. V.: Boreal forest fires in Siberia in 1998: Estimation of area burned and emissions of pollutants by advanced very high resolution radiometer satellite data, J. Geophys. Res., 107, 4745,doi:10.1029/2001JD001078, 2002.

Kasischke, E. S. and Bruhwiler, L. P.: Emissions of carbon dioxide, carbon monoxide, and methane from boreal forest fires in 1998, J. Geophys. Res., 108, 8146, doi:10.1029/2001JD000461, 2003.

Kasischke, E. S., Hewson, J. H., Stocks, B., Van der Werf, G., and Randerson, J.: The use of ATSR active fire counts for estimating relative patterns of biomass burning - a study from the boreal forest region, Geophys. Res. Lett., 30, 1969, doi:10.1029/2003GL017859, 2003.

Kato, S., Pochanart, P., Hirokawa, J., Kajii, Y., Akimoto, H., Ozaki, Y., Obi, K., Katsuno, T., Streets, D. G., and Minko, N. P.: The influence of Siberian forest fires on carbon monoxide concentrations at Happo, Japan, Atmos. Env., 36, 385-390, 2002.

Kim, Y. and Tanaka, N.: Effect of forest fire on the fluxes of $\mathrm{CO}_{2}$, $\mathrm{CH}_{4}$ and $\mathrm{N}_{2} \mathrm{O}$ in boreal forest soils, interior Alaska, J. Geophys. Res., 108, 8164, doi:10.1029/2001JD000663, 2003.

Kita, K. , Fujiwara, M., and Kawakami, S.: Total ozone increases associated with forest fires over the Indonesian region and its relation to the El Niño-Southern oscillation, Atmos. Env., 34, 2681-2690, 2000.

Lavoue, D. C., Liousse, C., Cachier, H., Stocks, B. J., and Goldammer, J. G.: Modelling of carbonaceous particles emitted by boreal and temperate wildfires at northern latitudes, J. Geophys. Res., 105, 26 871-26890, 2000.

Lipari, F., Dasch, J. M., Scuggs, W. F.: Aldehyde emissions from wood-burning fireplaces, Env. Sci. Techn., 18, 326-330, 1984.

Novelli, P. C., Masarie, K. A., Lang, P. M., Hall, B. D., Myers, R. C., and Elkins, J. W.: Reanalysis of tropospheric CO trends: Effects of the 1997-1998 wildfires, J. Geophys. Res., 108, 4464, doi:10.1029/2002JD003031, 2003.

Randerson, J. T., Field, C. B., Fung, I. Y., and Tans, P. P.: Increases in early season ecosystem uptake explain recent changes in the seasonal cycle of atmospheric $\mathrm{CO}_{2}$ at high northern latitudes, Geophys. Res. Lett., 26, 2765-2768, 1999.

Seinfeld, J. H. and Pandis, S. N.: Atmospheric chemistry and physics, John Wiley and Sons, Inc., New York, 1998.

Spichtinger, N., Wenig, M., James, P., Wagner, T., Platt, U., and Stohl, A.: Satellite detection of a continental-scale plume of nitrogen oxides from boreal forest fires, Geophys. Res. Lett., 28, 4579-4582, 2001.
Stocks, B. J., Fosberg, M. A., Lynham, T. J., Mearns, L., Wotton, B. M., Yang, Q., Jin, J.-Z., Lawrence, K., Hartley, G. R., Mason, J. A., and McKenney, D. W.: Climate change and forest fire potential in Russian and Canadian boreal forests, Clim. Change, 38 , 1-13, 1998.

Stohl, A.: A one-year Lagrangian "climatology" of airstreams in the northern hemisphere troposphere and lowermost stratosphere, J. Geophys. Res., 106, 7263-7279, 2001.

Stohl, A., Hittenberger, M., and Wotawa, G.: Validation of the Lagrangian particle dispersion model FLEXPART against large scale tracer experiment data, Atmos. Env., 32, 4245-4264, 1998.

Svidenko, A. and Goldammer, J. G.: Fire situation in Russia, IFFN, 24, 41-59, 2001.

United Nations Economic Commission for Europe: Timber Bulletin, Forest fire statistics 1996-1998, 52, 1999.

Tanimoto, H., Kajii, Y., Hirokawa, J., Akimoto, H., and Minko, N. P.: The atmospheric impact of boreal forest fires in far eastern Siberia on the seasonal variation of carbon monoxide: observations at Rishiri, a northern remote island in Japan, Geophys. Res. Lett., 27, 4073-4076, 2000.

Torres, O., Bhartia, P. K., Herman, J. R., Sinyuk, A., Ginoux, P., and Holben, B.: A long-term record of aerosol optical depth from TOMS observations and Comparison to AERONET measurements, J. Atmos. Sci., 59, 398-413, 2002.

Torres, O., Bhartia, P. K., Herman, J. R., Ahmad, Z., and Gleason, $\mathrm{J}$.: Derivation of aerosol properties from satellite measurements of backscattered ultraviolet radiation: theoretical basis, J. Geophys. Res., 103, 17 099-17 110, 1998.

Van der Werf, G., Randerson, J. T., Collatz, G. J., Giglio, L., Kasibhatla, P. S., Arellano, A. F., Olsen, S. C., and Kasischke, E. S.: Continental-scale partitioning of fire emissions during 1997 to 2001 El Niño/La Niña period: Science, 303, 73-76, 2004.

Wagner, T., Dix, B., Friedeburg, C. V., Frieß, U., Sanghavi, S., Sinreich, R., and Platt, U.: MAX-DOAS O4 measurements - a new technique to derive information on atmospheric aerosols, (I) Principles and information content, J. Geophys. Res., accepted, 2004.

Wotawa, G. and Trainer, M.: The influence of Canadian forest fires on pollutant concentrations in the United States, Science, 288, 324-328, 2000.

Wotawa, G., Novelli, P. C., Trainer, M., and Granier, C.: Interannual variability of summertime $\mathrm{CO}$ concentrations in the Northern Hemisphere explained by boreal forest fires in North America and Russia, Geophys. Res. Lett., 28, 4575-4578, 2001. 